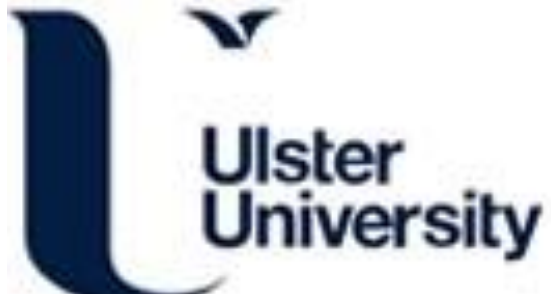

\section{A critical review of competitiveness measurement in Northern Ireland}

Birnie, E., Johnston, R., Heery, L., \& Ramsey, E. (2019). A critical review of competitiveness measurement in Northern Ireland. Regional Studies, 53(10), 1494-1504. https://doi.org/10.1080/00343404.2019.1569757

Link to publication record in Ulster University Research Portal

\section{Published in:}

Regional Studies

Publication Status:

Published (in print/issue): 03/10/2019

DOI:

10.1080/00343404.2019.1569757

\section{Document Version}

Author Accepted version

\section{General rights}

Copyright for the publications made accessible via Ulster University's Research Portal is retained by the author(s) and / or other copyright owners and it is a condition of accessing these publications that users recognise and abide by the legal requirements associated with these rights.

\section{Take down policy}

The Research Portal is Ulster University's institutional repository that provides access to Ulster's research outputs. Every effort has been made to ensure that content in the Research Portal does not infringe any person's rights, or applicable UK laws. If you discover content in the Research Portal that you believe breaches copyright or violates any law, please contact pure-support@ulster.ac.uk. 


\section{A critical review of competitiveness measurement in Northern Ireland}

Esmond Birnie $^{\mathrm{a} *}$, Richard Johnston ${ }^{\mathrm{b}}$, Laura Heery $^{\mathrm{c}}$ and Elaine Ramsey ${ }^{\mathrm{d}}$

${ }^{a}$ Ulster University Economic Policy Centre, Ulster University at Jordanstown, Newtownabbey, Northern Ireland, UK, BT37 OQB. esmond.birnie@ulster.ac.uk;

${ }^{\mathrm{b}}$ Ulster University Economic Policy Centre, Ulster University at Jordanstown, Newtownabbey, Northern Ireland, UK, BT37 0QB. richard.johnston@ulster.ac.uk;

${ }^{c}$ Ulster University Economic Policy Centre, Ulster University at Jordanstown, Newtownabbey, Northern Ireland, UK, BT37 0QB. 1.heery@ulster.ac.uk;

and ${ }^{\mathrm{d}}$ Ulster University Business School, Ulster University at Coleraine, Coleraine, Northern Ireland, UK, BT52 1SA. e.ramsey@ulster.ac.uk 


\section{Abstract}

Measurement of regional competitiveness is an important and complex issue.

Previous research has mostly considered national economies. However, indicators and measures identified at the national level may not apply well to regions. This paper contributes to knowledge by providing an analytical narrative of how the concept of the measurement of competitiveness has developed over time in Northern Ireland. The various stages in the development of measurements are critically evaluated. The region's chronic competitiveness shortfall is identified and possible explanations are indicated. The conclusions assess the most recent position regarding competitiveness measurement alongside a review of future research needs.

Keywords: Competitiveness; productivity; regional; economic development policy; Northern Ireland

Subject classification codes: E01, L11, O18, R11

\section{Introduction}

Competitiveness is an important matter because more competitive regions/countries are also likely to have high and rising living standards and thriving businesses. Admittedly, the strength of that positive connection through to economic performance depends somewhat on the way in which competitiveness is measured (Porter, 1990; Delgado, Ketels, Porter \& Stern, 2012; Ketels, 2016). Sometimes, the pursuit of a higher ranking may have become obsessive (Kitson, Martin \& Tyler, 2004). Certainly, competitiveness has played a central role in policy statements. For example, the UK government's White Paper on industrial strategy in November 2017 and the Northern Ireland draft Industrial Strategy published in January 2017. All this reflects a longstanding perception in Northern Ireland, and in the UK in general, that competitiveness remains a fundamental challenge, which must be resolved in order to deliver performance improvements ( DTI, 2004; HM Treasury, 2004; Birnie \& Brownlow, 2017).

The earliest measurements of competitiveness in Northern Ireland were comparisons of productivity levels relative to the UK average. This was later broadened into a consideration of indicators and possible explanations of competitiveness using the World Economic Forum (WEF) 
Index. Most recently, a measure derived from the Republic of Ireland's National Competitiveness Council (NCC) was applied, albeit with modifications. Previous research has considered how to define, measure and explain competitiveness at the level of national economies (Schwab, 2009), and indicators and measures identified as relevant at that level may not always apply well to a regional economy. The paper considers this and other limitations as part of a critical review of how the measurement of competitiveness has developed over a long period of time. The originality of the paper is that such a review has not been done before for Northern Ireland, and probably not for other UK regions.

As such, it will add to previous research on competitiveness by using Northern Ireland as a case study of the way in which the concept of competitiveness and the method of measurement of competitiveness has developed over time in a region and focuses particularly on:

(1) Measurement of the recent comparative productivity of the Northern Ireland economy relative to both the UK average and OECD/ EU economies- given the emphasis on productivity in the international literature on competitiveness;

(2) An evaluation of the application of one of the international indices of competitiveness, the WEF, to Northern Ireland- given the emphasis in some of the literature on a wider range of indicators;

(3) Consideration of how the NCC approach to measuring competitiveness was applied to Northern Ireland in a modified form- given an identification of possible weaknesses in the WEF-based approach; and

(4) Consideration of implications for future policy and research.

The paper is structured as follows. Firstly definitions of competitiveness are delineated within the context of measurements. This is then followed by a summary of Northern Ireland's recent performance in terms of comparative productivity. That is followed by a review of the inclusion of the region in the WEF Index. The application to Northern Ireland of a modified version of the NCC is then considered. We conclude with some considerations relating to possible future research. 


\section{Defining competiveness}

Use of the term competitiveness creates the possibility that it is a "conceptual chimera" (Budd \& Hirmis, 2004) which does not necessarily have much analytical content. Berger and Bristow (2009) fear measurements have been conducted without an underlying coherent conceptual framework. There have, however, been attempts to give the concept of competitiveness a more precise meaning. One view, for example, is that competitiveness should be defined as the ability of businesses to sell their products and services whilst also paying high and rising wages (NCC, 2017). If competitiveness is defined in this way then in practical terms it approximates to a high and rising level of labour productivity: output per worker or per hour worked. The WEF, International Institute of Management Development (IMD), Porter (1990, 2000), and Delgado, Ketels, Porter \& Stern (2012) have all expressed sympathy for such an approach to defining competitiveness. OECD (1996) defined competitiveness as:

'The degree to which it [i.e. the nation/region] can, under free and fair market conditions, produce goods and services which meet the test of inter-national markets, while simultaneously maintaining and expanding the real incomes of its people over the long term' ${ }^{1}$

Admittedly, some commentators such as Krugman (1994) fear a definition such as Porter's promotes a zero-sum game whereby countries (regions) race or fight to increase their competitveness at the expense of others. ${ }^{2}$ Greater competitiveness in terms of higher market share clearly is zero sum but in principle all countries could maintain existing market shares but also each raise their productivity levels- they would all be better off. Krugman (1990) concedes the critical importance of productivity as the main determinant of living standards, "Productivity isn't everything, but in the long run it is almost everything".

The approach here is similar to the OECD's has been taken by the UK Competitiveness Index (UKCI) which considers competiveness across the cities and regions of Great Britain 
(Huggins, 2003; Huggins \& Thompson, 2016). In the UKCI a region is considered competitive if it can attract and maintain firms, which are able to retain existing market shares or increase those shares whilst at the same time the standard of living of the population is either maintained or increased.

The emphasis on productivity may imply that we avoid making statements about competitiveness such as 'a highly competitive region generates high and rising living standards, such high living standards are caused by the region being competitive' which are true in only a trivial or tautological sense. To the extent that competitiveness is driven by productivity then, we can apply the considerable body of research relating to explanations of differences in productivity levels at the international, national and regional levels (Prais, 1981; Smith, Hitchens \& Davies, 1982; OECD, 2017). Importantly, if competitiveness is defined in terms of productivity then the extensive range of factors, including some of the so-called 'soft factors', which have been identified as explanations of comparative productivity are also the drivers of competitiveness: capital stock, skills, management capabilities, innovation, firm and market size, extent of competition in the market, institutions etc (Kitson Martin \& Tyler, 2004).

Martin \& Tyler (2003) argue competitiveness is not necessarily tightly linked to productivity given the possible influences of increasing returns, external or agglomeration economies and endogenous growth. Budd \& Hirmis (2004), however, stress that a high level of productivity is important as an indicator of how far firms have managed to overcome $\mathrm{X}$ inefficiency: the extent to which slack in terms of management or labour force practices leads to a less than optimal level of output given the level of inputs to the production process. Earlier studies have suggested that $\mathrm{X}$-inefficiency has been particularly important in the case of Northern Ireland (Crafts, 1995).

An alternative approach to defining competitiveness focuses more on the costs of doing business such as the costs of labour or energy or transport and the extent to which these costs allow firms to compete. In such a costs-based approach there are, as Krugman (1994) has noted, some dangers in drawing too tight an analogy between a business and a region/country. A business that is uncompetitive on costs may go out of business, but an entire regional economy cannot do 
that, but the sectoral structure may adjust. ${ }^{3}$ However, as the NCC (2017) noted, it should be possible in practice to combine an emphasis on comparative productivity with one on relative costs. A justification for doing this was provided by Ketels (2016) when he argued that productivity plays a key role in determining competitiveness in the long run whereas relative costs certainly matter in the short run, and may be particularly important as determinants of in-flows of foreign direct investment (FDI). One of the often-used measures of international competitivenessrelative unit labour costs- is a mathematical combination of the productivity-based and cost-based approaches (Durand \& Giorno, 1987). ${ }^{4}$

Ketels (2016) also noted that the international literature on competitiveness was increasingly emphasising the importance of considering competitiveness at the regional as well as national level. The factors that determine competitiveness at this meso level may differ from those which rule at either the macro level (national economy) or micro level (businesses) (Cellini \& Soci, 2002). The distance-destroying capacity of modern (information) technology may have been exaggerated: 'geography is not dead' (Morgan, 2004). Especially in terms of economic geography and urbanization, there could be location-specific drivers of productivity and competitiveness. For example, the extent of business clustering based on agglomeration economies may become especially relevant at the regional level. Regions are often more powerfully impacted by the mobility of labour and capital than countries (Budd \& Hirmis, 2004) because of the greater proportional scale of those flows.

Additionally, Ketels pointed to the value of considering measures of well-being as well as GDP given a growing sense of the limitations which relate to the conventional measures of economic output (Stiglitz, Sen \& Fitoussi, 2009). If competitiveness is considered as very closely related to productivity then competitiveness improvement could be a means rather than an end: a means towards the goal of higher livings standards. In such a case, the quality of life will be important as will be the extent to which such high levels of productivity, competitiveness and living standards are sustainable. ${ }^{5}$ The NCC approach treats competitiveness as a means to the end of higher and more sustainable living standards. Not only can well-being be considered as an 
outcome of competitiveness, to some extent it may be an explanation as well. If the quality of life in a region is increased this increases the likelihood that individuals or businesses will wish to locate in that region (Balykte \& Mtvaronavičene, 2010).

\section{Northern Ireland competitiveness considered in terms of comparative productivity}

Some of the earliest considerations of the comparative competitiveness and performance of the Northern Ireland economy focused on productivity (Isles \& Cuthbert, 1957). This approach continued for some time (Hitchens, Wagner \& Birnie, 1990; IREP, 2009). Measurement wise, this was tricky and there are some considerations relating to the data.

Measurement of labour productivity ${ }^{6}$ relies on accurate measurement of output such as GDP or GVA ${ }^{7}$ data, as well as an accurate measurement of the labour input. In a Northern Ireland context, GVA data taken from the regional accounts could be used. There may be issues relating particuarly to measuring output in the public sector, allocation of output across multi-regional businesses and the impact of price differences between regions.

Figure 1 presents data relating to comparative productivity of the overall Northern Ireland economy, as measured by GVA per hour worked, in terms of both level and growth during 201015 in international terms, the comparators being the OECD economies:

\section{[INSERT FIGURE 1 HERE]}

Figure 1 illustrates that Northern Ireland's relative productivity levels were just above the international average in 2015, albeit with little or no productivity growth during 2010-15, representing one of the lowest productivity growth economies. UK productivity levels were also above the international average, albeit, as in Northern Ireland, growth rates were low by international standards. Republic of Ireland recorded a strong performance, increasing productivity from what was an already high level. Part of the explanation for this is that the Republic of Ireland reduced employment by more than the UK during the 2008-9 recession and 
then had a shallower jobs recovery. Importantly, whereas the figures indicate a productivity shortfall compared to the UK average in the mid 2010s, earlier studies indicate a similar position in the 1980s or 1920s-40s (Isles \& Cuthbert, 1957; Hitchens, Wagner \& Birnie, 1990).

Figure 2 illustrates the comparison of Northern Ireland's productivity level with other UK regions:

\section{[INSERT FIGURE 2 HERE]}

Northern Ireland's relative productivity was low compared to other UK regions: about $16 \%$ points below the UK average in 2015 . This productivity gap was partly explained by Northern Ireland's sectoral structure where the majority of people employed in the economy work in what are in general lower productivity sectors (e.g. agriculture and retail and some other service sectors). The proportion of the total productivity gap relative to the UK average explained by such structural factors was about one-half (Johnston \& Buchanan, 2016). Northern Ireland was not able to improve its comparative position during 2010-15.

In Figure 3 the NI/UK comparisons are illustrated at a sectoral level:

\section{[INSERT FIGURE 3 HERE]}

Sectoral productivity in Northern Ireland lags the UK average in the majority of sectors. In 2015, two of the sectors in which Northern Ireland had higher productivity were in the public sector; water supply, and public administration. Given that public sector productivity is made up largely of wages per employee (as the sector does not generate profits) with these representing about three-fifths of sectoral GVA, relatively high wages as compared to GB, were being reflected. This in turn reflects the extent to which Northern Ireland has a higher proportion of people working in the public sector at higher grades as compared to the rest of the UK, given a proportionally higher number of top positions in departments, councils and Non-Departmental Public Bodies (NDPBs). 
Johnston \& Buchanan (2016) indicate that the other major component of value added in the public sector, non-market capital consumption (NMCC), was higher in Northern Ireland compared to the UK average. NMCC is an accounting adjustment in the national and regional accounts to reflect the depreciation of a proportionally larger capital stock in the Northern Ireland public sector. NMCC as a proportion of GVA is higher than any other UK country and has been so from the start of the data series in 1997. In 2015, for example, in public administration NMCC represented $40.2 \%$ of the sectoral GVA in Northern Ireland but only $27.3 \%$ for that sector in the UK overall.

Northern Ireland agricultural productivity is indicated as very low in comparative terms. This is consistent with earlier studies (Birnie, 1997) and may be because farm sizes are smaller on average.

\section{Measuring Northern Ireland's competitiveness based on the WEF}

Whilst the literature on competitiveness has often focused on comparative productivity, it has also highlighted a wider range of indicators, some of which are considered as the likely explanations of the comparative productivity performance. The WEF, for example, defines competitiveness as:

'The set of institutions, policies and factors that determine the level of productivity in a country. The level of productivity, in turn, sets the sustainable level of prosperity that can be earned by a country' (Schwab, 2009).

The WEF Index, as one amongst a number of international indices of competitiveness, assessed competitiveness in 144 national economies during 2012-13, providing insight into the drivers of productivity and prosperity. Competitiveness dimensions were reported across 12 pillars or thematic areas which together make up the Global Competitiveness Index. Approximately twothirds of the data were sourced from an executive opinion survey and the remaining third were official statistics from publicly available sources. 
The WEF approach was applied to Northern Ireland by SQW/Cambridge Econometrics (2013) in research commissioned by the Economic Advisory Group (EAG), conducted in 2012. It is worth stressing this was the first time the WEF had been applied to a region. 100 chief executives of public sector and private organisations/businesses in Northern Ireland were asked a wide range of questions relating to their perception of how Northern Ireland performed with respect to the main drivers of competitive performance. Northern Ireland was ranked $42^{\text {nd }}$ of the 145 countries $^{8}$ ranked using the WEF index, scoring 4.46 out of 10 . The Republic of Ireland was ranked $27^{\text {th }}$ and the UK $8^{\text {th }}$. Switzerland was ranked first, followed by Singapore, Finland and Sweden in that order.

Regarding the twelve pillars or drivers of competitiveness within the WEF index, Northern Ireland performed relatively well in terms of health and primary education, higher education and training; and goods market efficiency; and was at its weakest in terms of macroeconomic environment, to the latter reflecting the fact that Northern Ireland is a small region of the UK and so was likely to score badly on the availability of fiscal policy tools and the size of the home market. ${ }^{9}$

\section{[INSERT TABLE 1 HERE]}

Measuring Northern Ireland's regional competitiveness based on the WEF had a number of advantages:

- Comparisons to a large number of countries;

- A wide range of explanatory factors could be considered; and

- If this study was repeated over time it would be possible to trace Northern Ireland's changing position in the global competitiveness rankings both at the aggregate level and in terms of individual explanatory factors.

However, there were also some limitations: 
- It was not possible to include additional indicators thought to be particularly relevant to Northern Ireland;

- The WEF methodology included many indicators that are set at a national level and are therefore outside the control of policy makers in Northern Ireland;

- Most of the data were taken from an executive opinion survey which raises the potential that the data could be skewed by opinion rather than evidence;

- WEF produces the composite or average ranking across the pillars using standardised weightings. This raises a number of issues (Ketels, 2016). For example, are the weights correct (Bowen and Moesen, 2011)? Is enough allowance given to the fact that two countries could have similar rankings but achieve that position in different ways? Do the same movements in terms of rankings (say, $10^{\text {th }}$ to $5^{\text {th }}$ and $15^{\text {th }}$ to $10^{\text {th }}$ ) really represent the same 'distance' in terms of competitiveness?;

- The reliance on rankings and particularly use of a composite index may encourage the perception that competitiveness is only a zero sum game: as one country gains another inevitably loses; and

- Comparisons are made to a very disparate collection of countries. ${ }^{10}$

\section{The Competitiveness Scorecard: Modified version of NCC}

An appreciation of some of the limitations of the WEF when applied at the regional level, led policy makers in Northern Ireland to decide to move away from that approach. ${ }^{11}$ It was felt that it would be better to compare Northern Ireland to a smaller peer group restricted largely to developed economies. Additionally, a range of indicators were recommended which would be similar in broad terms to those used by the NCC in the Republic of Ireland, though with some adaptation to allow for the particular circumstances in Northern Ireland.

The approach taken can be summarised in the following "pyramid" diagram (similar to one used by NCC): 


\section{[INSERT FIGURE 4 HERE]}

The top of the pyramid represented the goal or end objective of competitiveness, sustainable growth. Such sustainable growth was measured in terms of three groups or pillars of indicators: Macro and fiscal sustainability, quality of life and environmental sustainability. In the middle of the pyramid lay the essential conditions which were necessary to reach the objective of sustainable growth. Finally, four groups of indicators at the bottom of the pyramid summarised the various areas where policy makers could exercise a critical influence.

The NCC framework strongly influenced the Scorecard but a number of modifications were introduced (Johnston \& Heery, 2016):

- Sectoral consideration represented by the consideration of comparative productivity at the sectoral level;

- Quality of life measures were added (which is consistent with the emphasis that social cohesion should be an integral component of regional competitiveness: EC (2004));

- Additional indicators (e.g. the extent of sea and air transport connections and relative industrial energy prices);

- More detail regarding the impact of knowledge (the NCC knowledge infrastructure theme was sub-divided into two separate pillars: education and skills, and innovation, $R \& D$ ); and

- Comparisons were made with other UK regions when the data allowed.

Northern Ireland's relative competitiveness in 2015 , or the most up to date year in which an international comparison was possible for each element or pillar of the Competitiveness Scorecard is illustrated in Figure 5. A score closer to zero or the centre of the diagram is good. A score of one indicates a presence in the best decile of international performers whereas ten indicates being in the least well performing decile. Figure 5 shows that Northern Ireland's business environment, quality of life and business performance pillars scored best in relative terms and that productivity, employment and labour supply and macro and fiscal were the worst. 


\section{[INSERT FIGURE 5 HERE]}

Northern Ireland's overall competitiveness performance improved slightly over the five years to 2015 based on a simple average of the scores across the 11 pillars. However, the average score remained well below average for the countries analysed in the Competitiveness ScorecardNorthern Ireland continued to be placed in the sixth decile of countries.

Table 2 provides more detail as to performance by showing any change during 2010-15 in terms of each of the 11 pillars. These pillars are ranked with the those experiencing the largest improvement placed at the top of the table. The largest improvement was in the business performance pillar, driven by increasing number of businesses, as well as more churn in that stock of businesses ${ }^{12}$ and by growth in the rate of foreign direct investment (FDI) investment. The physical infrastructure and macro and fiscal pillars also improved slightly. Education and skills and employment and labour supply were the only two pillars in which Northern Ireland's relative performance deteriorated. In those cases Northern Ireland's performance had improved in absolute terms but competitor nations advanced more rapidly and so outpaced Northern Ireland.

\section{[INSERT TABLE 2 HERE]}

In terms of the pyramid concept of competitiveness (see Figure 5) the following summary can be made, particularly in terms of the three layers:

\section{Sustainable growth}

Northern Ireland did do well compared to the rest of the UK in terms of high levels of life satisfaction and quality of life, but that position was much less strong in comparative international terms. Performance in terms of the macro and fiscal pillar was particularly weak, attributable to Northern Ireland having a relatively small private sector and a relatively large regional fiscal 
deficit. Northern Ireland also recorded relatively weak performance in terms of environmental sustainability as indicated by the low percentage of energy generated from renewable sources.

\section{Essential conditions}

More than two-thirds of countries scored ahead of Northern Ireland. The productivity pillar as this was indicated as the weakest of the pillars contained in the Scorecard. Northern Ireland's comparative productivity performance has been poor for a very long period of time as was indicated earlier in this article. Growing productivity will be a key policy challenge. In terms of the prices and costs pillar, Northern Ireland scored well in terms of house price affordability and business water charges, but ranked poorly when industrial electricity charges were considered. Northern Ireland had a relatively weak performance in terms of a number of indicators within the employment and labour supply pillar.

\section{Policy inputs}

The lowest or foundation tier of the pyramid (policy inputs)- was the best performing tier of the Scorecard in terms of improvements in the decile position. This could imply that improvements are likely in the sustainable growth and essential conditions tiers, as the impact of policy inputs feed through over time. Northern Ireland was still below average in international terms in terms of its ranking within the peer group.

Significant improvements were made in terms of the absolute level of education and skills over the five years. Despite these improvements, Northern Ireland's relative competitiveness in this pillar fell back as other nations improved more rapidly. Issues emerged in terms of mathematical and scientific literacy and the large proportion of the population with low qualifications (UUEPC, 2017).

Business environment was the best performing pillar within the Scorecard, driven by strong UK credentials in areas such as regulation. ${ }^{13}$ Physical infrastructure benefitted from Northern Ireland's relatively advanced technological infrastructure which produced good scores for internet and broadband connections; a relatively high dependence on imported energy counted 
against Northern Ireland, as did a low number of air and sea route connections to and from the region.

\section{Implications for future policy and research}

The policy concept of competitiveness and hence its measurement has shown considerable development over the last half century. The earliest considerations were in the mid 1950s, which focused on productivity (Isles \& Cuthbert, 1957). This approach was repeated in the 1980s (Hitchens, Wagner \& Birnie, 1990). In the early 2010s, attention moved to a wider range of indicators, albeit many of these related to productivity, as used by the WEF index. Most recently, a modified version of the NCC approach has been adopted in the form of the Scorecard.

It could be argued that the most recent approach represents an improvement because a greater number of indicators are being used and Northern Ireland is being compared to a wider peer group (mainly OECD countries) rather than just to the UK average. At the same time, a number of aspects of the Scorecard may require further attention especially in terms of a research agenda to better inform policy.

R\&D was an important indicator within the Scorecard. It is one of a number of variables that is likely to influence not only productivity/competitiveness, but also total factor productivity. There has been a very substantial growth in business R\&D spend in real terms during 2008-15 (NISRA, 2017). This increase was almost entirely concentrated amongst larger, externally owned (GB and foreign) businesses and in the most recent data total spend declined; falling 5\% in real terms between 2015 and 2016 (NISRA, 28 November 2017). Particularly from a policy point of view, an investigation of the barriers to increased $R \& D$ activity amongst the locally owned businesses- usually the smaller ones- in Northern Ireland could be worthwhile. This points to a broader issue. The various measures of competitiveness try to measure "average" competitiveness across the entire economy. Some disaggregation- for example in terms of small and medium sized enterprises and particularly issues relating to entrepreneurship- might be useful to policy makers. ${ }^{14}$ 
Ketels(2016) argued that the sophistication of firms could be a determinant of competitiveness. Firm sophistication might be proxied by, for example, an up-date of an earlier measure of comparative use of management techniques in Northern Ireland (DETI, DEL, Invest NI, InterTradeIreland \& Forfas, 2009). Northern Ireland was ranked below seven countries (US, Germany, Sweden, Japan, Italy, GB and Poland, in that order) and above five (Republic of Ireland, Portugal, Greece, China and India, in that order). The case for considering comparative management practices in Northern Ireland is strengthened given that ONS (2017b) conducted a comparative survey of about 1,000 businesses in Great Britain, but not including Northern Ireland, and demonstrated a strong association between the use of management practices and levels of productivity. What we do know, which is suggestive of a shortfall in management capacity, is that the percentage of the overall Northern Ireland labour force qualified to degree level is lower than the overall UK average (OECD, 2017). A broader consideration of firm sophistication might also consider the nature and extent of business clusters in Northern Ireland (Marshall, 1920; Porter 1998). Matrix (2008) identified some clusters but the Centre for Cities (2014) considered only the regions of Great Britain.

In contrast to the SQW/Cambridge Econometrics (2013) measure, the UUEPC Scorecard did not attempt to measure the impact of governance and institutions in Northern Ireland. The WEF Index includes a range of questions such as how far there is trust in politicians and transparency in decision making: in 2012 Northern Ireland fell behind the UK average in terms of these indicators. Given the somewhat stop-go nature of devolution in Northern Ireland since 1999 and recurrent political crises since 2014, a strong case can be made that a competitiveness index for Northern Ireland should include some sort of proxy for the impact of the institutions and associated political uncertainty. NCC do include measures of the comparative effectiveness of government and other institutions in the Republic of Ireland.

In modifying the NCC approach, the decision was taken to include an extensive range of indicators, which might proxy for quality of life. This was consistent with the growing international emphasis on well-being measures (Helliwell, Layard \& Sachs, 2016) and also with an increasing emphasis on these in Northern Ireland policy making (DfE, 2017). Competitive 
regions are going to be areas where people want to live, work and invest. However, the fact that the ONS measure of life satisfaction for Northern Ireland is so much higher than the UK average and other UK regions is somewhat question begging. ${ }^{15}$ Given that the Scorecard used only one of the ONS indicators of well-being at the regional level (according to most of the individual measures Northern Ireland lagged the UK average) a case could be made for some sort of average or blended measure. Alternatively, it may be that the existing well-being measures are too problematic to be applied.

A general criticism of the NCC-based approach could be that it represents too much of a shift towards indicators which were readily quantifiable and especially those measured through official statistics. A case might be made for some elements of a more subjective approach similar to that used by the $\mathrm{WEF}^{16}$ whereby areas such as the relative strength of the business environment, ${ }^{17}$ innovation systems, entrepreneurship and the quality of skills might be elucidated through interviews with CEOs.

A benchmark measure such as the Scorecard will be most useful if it is used as a basis for longitudinal research and analysis. Similar data should be collected in the future in order to investigate how the level of competitiveness in Northern Ireland changes over time. In this context it is also worth noting that the most recent draft Northern Ireland Industrial Strategy (DfE, 2017) hinted that the policy on measuring the region's competitiveness might be about to experience a further shift. This was implied given the emphasis that the Strategy gave to comparative analysis of Northern Ireland's economic performance against a group of small advanced economies.

DfE (2017) identified Singapore, Republic of Ireland, Denmark, Finland, Scotland, Israel, New Zealand and Estonia as the most appropriate peer group against which to make comparisons. This leads on to the question as to whether to continue with the wider range of comparisons in the Scorecard (comparing Northern Ireland to the 30 or so OECD/Eurostat countries using about 150 indicators) or to restrict comparisons to the eight other small advanced economies? ${ }^{18}$ The advantage of retaining the previous Scorecard approach is the wider 
range of data, based on about 150 indicators as opposed to 20 in the DfE small economies comparisons. Additionally, reducing the peer group to only eight countries may introduce subjectivity: the bar may be lowered by introducing "weaker" comparators. ${ }^{19}$ The disadvantage of the wider range of comparisons contained in the Scorecard is that sometimes comparisons may become less interesting when Northern Ireland is being compared to much larger and therefore very different economies such as Germany, Japan, US and Brazil.

Brexit is relevant although the extent of any impact on the Northern Ireland economy remains uncertain. What could be said is that to the extent frictions to trade are increased then the importance of improving competitiveness increases. A review of policy options in Scotland has stressed the importance of improving the country's competitiveness rankings (Sustainable Growth Commission, 2018).

\section{Conclusions}

There is a considerable body of literature on competitiveness, but there are some limitations in that research, which we have tried to unpick. Notably, in terms of adequately translating measures of competitiveness down from the level of the national economy to regional economies. Also, there have been only limited extensions of the definition of competitiveness to include quality of life and well-being. This article moves into those research gaps and in particular used Northern Ireland as a case study of how the concept of competitiveness and particularly the measurement of competitiveness changed over time. The originality of the article lies in the analytical narrative of how the approaches to competitiveness measurement evolved from the productivity comparisons of the 1950s and 1980s through to several versions of competitiveness indices in the 2010s (WEF and Competitiveness Scorecard). One survey of international practice regarding regional competitiveness concluded that, '...there is an elusive concept, flawed indicators and over-prescribed policies' (Kitson, Martin \& Tyler, 2004). The Northern Ireland experience may evidence all of those problems but it is also notable how competitiveness measures have been 
refined and broadened and therefore probably improved over time. We note how there is still scope to improve the measure by further research and data collection.

The Competitiveness Scorecard is a distinctive approach to the definition of competitiveness at the regional level given that it contrasts to the WEF-based measurement and also modified the NCC approach. The Scorecard provided a comprehensive overview of Northern Ireland's relative competitiveness with more than 150 indicators across 11 thematic elements. It is of note that the Scorecard included well-being amongst its indicators however there may be grounds for further refining the measurement of $R \& D$ activity and for introducing some indicators relating to management quality, and institutional and political instability.

Although the Scorecard was a partial measure there are grounds for believing this particular measure represented an improvement on what went before. The results produced by the Scorecard provide a realistic and useful assessment for policy makers. Northern Ireland's relative competitiveness improved slightly during 2010-15 but remained below average for the OECD countries. These findings highlight the scale of the competitiveness challenge for Northern Ireland. More importantly, it highlights that action must be taken in order to boost relative competitiveness in order to improve Northern Ireland's performance and grow the economy, delivering higher standards of living for all ${ }^{20}$

\section{References}

Balkyte, A. \& Mtvaronavičene, M. (2010). Perception of competitiveness in the context of sustainable development: Facets of sustainable competitiveness. Journal of Business Economics and Management, 11, 341-65.

Berger, T. \& Bristow, G. (2009). Competitiveness and benchmarking of nations- A critical reflection. International Advanced Economic Research, 15, 378-92.

Birnie, J.E. (1997). Irish farming labour productivity: Comparisons with the UK, 1930s1990. Irish Economic and Social History, 24, 22-41.

Birnie, E. \& Brownlow, G. (2017). Should the fiscal powers of the Northern Ireland Assembly be enhanced? Regional Studies, 51, 1429-39. 
Bowen, H.P. \& Moesen, W. (2011). Composite competitiveness indicators with endogenous weights versus predetermined weights. An application to the World Economic Forum's global competitiveness index. Competitiveness Review: An International Business Journal, 21, 2, 129-51.

Budd, L. \& Hirmis, A. (2004). Conceptual framework for regional competitiveness. Regional Studies, 38, pp. 1015-28.

Byrne, T. (2017). Benchmarking Northern Ireland's Competitiveness against Small Advanced Economies. Belfast: Department for the Economy.

Cellini, R. \& Soci, A. (2002). Pop competitiveness. Banca Nazionale del Lavoro Quarterly Review, 55, 7-101.

Centre for Cities. (2014). Industrial Revolutions: Capturing the Growth Potential, London: Centre for Cities and McKinsey \& Company.

Crafts, N.F.R. (1995). The Golden Age of economic growth in postwar Europe: Why did Northern Ireland miss out? Irish Economic and Social History, 22, 5-25.

Delgado, S., Ketel,C., Porter, M. \& Stern, S. (2012). The determinants of national competitiveness. NBER Working Paper, 18249. Cambridge MA: National Bureau for Economic Research.

DETI, DEL, Invest NI, InterTradeIreland \& Forfas (2009). Management Matters. Belfast: Department for Enterprise, Trade and Investment.

DfE (2017). Economy 2030: A Consultation on an Industrial Strategy for Northern Ireland. Belfast: Department for the Economy.

DTI (2004). Regional Competitiveness and the State of the Regions. London: Department of Trade and Industry.

EC (2004). A New Partnership for Cohesion: Convergence, Competitiveness and Cooperation. Brussels: European Commission. 
Durand, M. \& Giorno, C. (1987). Indicators of international competitiveness: Conceptual aspects and evaluation. OECD Economic Studies. Paris: Organisation for Economic Cooperation and Development.

Ha-Joon, C. (2013). Economics: An Outline Guide. London: Penguin.

Helliwell, J., Layard, R. \& Sachs, J. (2016). World Happiness Report 2016. New York: Sustainable Development Solutions Network.

Hitchens, D.M.W.N., Wagner, K. \& Birnie, J.E. (1990). Closing the Productivity Gap. Aldershot: Avebury.

Huggins, R. (2003). Creating a UK competitiveness index: Regional and local benchmarking. Regional Studies, 37, 89-96.

Huggins, R. \& Thompson, P. (2016). UK Competitiveness Index 2016. Cardiff and Nottingham: Cardiff University and Nottingham Trent University.

IREP (2009). The Independent Review of Economic Policy. Belfast: Independent Review of Economic Policy.

Isles, R. and Cuthbert, N. (1957). The Northern Ireland Economy. Belfast: Her Majesty's Stationery Office.

Johnston, R. and Buchanan, J. (2016). Understanding productivity in Northern Ireland. Belfast: Ulster University Economic Policy Centre.

Johnston, R. and Heery, L. (2016). Competitiveness Scorecard for Northern Ireland. Belfast: Ulster University Economic Policy Centre.

Ketels, C. (2016). Review of competitiveness frameworks. (An Analysis Conducted for the Irish National Competitiveness Council). Dublin: National Competitiveness Council. Kitson, M., Martin, R. \& Tyler, P. (2004). Regional competitiveness: An elusive yet key concept? Regional Studies, 38, 9, 991-9.

Krugman, P. (1990). The Age of Diminishing Expectations. Cambridge MA: MIT Press. 
Krugman, P. (1994). Competitiveness: A dangerous obsession. Foreign Affairs, 73, $28-$ 44.

Marshall, A. (1920). Principles of Economics. Cambridge: Macmillan.

Martin, R \& Tyler, P. (2003). Regional competitiveness: An elusive concept. Regional Studies Conference, April. Pisa.

Matrix (2008). First Report of Matrix: The Northern Ireland Science Industry Panel. Belfast: Matrix/Northern Ireland Science Industry Panel.

McFetridge, D.G. (1985). Competitiveness, conceptual measures. Occasional Paper, 1, Ottawa: Industry Canada.

Morgan, K. (2004). The exaggerated death of geography: Learning, proximity and territorial innovation systems. Journal of Economic Geography, 4, 3-22.

NCC (2017). Benchmarking Competitiveness: Ireland and UK 2017. Dublin: National Competitiveness Council.

NISRA (28 November 2017). Northern Ireland R\&D Headline Statistics 2016. (Press release). Belfast: Northern Ireland Statistics and Research Agency.

OECD (2017). Economic Surveys: UK. Paris: Organisation for Economic Co-operation and Development.

ONS (2016a). Measuring national well-being. (Statistical Bulletin). Newport: Office for National Statistics.

ONS (2016b). Public service productivity estimates: Total public services, 2013. (Statistical Bulletin). Newport: Office for National Statistics.

ONS (2017a). Regional and sub-regional productivity in the UK. (Statistical Bulletin). Newport: Office for National Statistics. 
ONS (2017b). Management practices and productivity among manufacturing businesses in GB: Experimental estimates for 2015. (Statistical Bulletin). Newport: Office for National Statistics.

Porter, M. (1990). The Competitive Advantage of Nations. New York: Free Press.

Porter. M. (1998). Location, clusters and the new economics of competition. Business Economics, 33, 7-17.

Porter, M. (2000). Location, competitiveness and economic development: Local clusters in the global economy. Economic Development Quarterly, 14, 15-34.

Prais, S.J. (1981), Productivity and Industrial Structure. Cambridge: Cambridge University Press.

Schwab, K. (2009). The Global World Competitiveness Report 2009-10. Geneva: WEF. Smith, A.D., Hitchens, D.M.W.N. \& Davies, S.W. (1982). International Industrial Productivity: A Comparison of Britain, America and Germany, Cambridge University Press, Cambridge.

SQW/Cambridge Econometrics (2013). Competitiveness Index for Northern Ireland. (Report). Cambridge: Cambridge Econometrics.

Stiglitz, J., Sen, A. \& Fitoussi, J.P. (2009). Report by the Commission on the Measurement of Economic Performance and Social Progress. Paris: OECD.

Storper, M. (1997). The Regional World: Territorial development in a Global Economy. New York: Guilford Press.

Sustainable Growth Commission (2018). Scotland-The New Case for Optimism: A Strategy for Inter-generational Economic Renaissance. Edinburgh: Sustainable Growth Commission.

UUEPC (2017). Skills Barometer. Belfast: Ulster University Economic Policy Centre. 
${ }^{1}$ This is very similar to Storper's (1997) definition of "place competitiveness".

${ }^{2}$ Given traditional trade theory, even the low productivity country will still have comparative advantage in some activities and should be able to specialise in these.

${ }^{3}$ Here, again, the theory of comparative advantage is relevant. In a trading context countries can gain economically by specializing in those activities where they have relative cost advantage even if in absolute terms they have higher production costs across the whole range of goods and services.

${ }^{4}$ Relative unit labour costs are calculated by dividing relative wages and by relative productivity (both in common currency terms).

${ }^{5}$ Interestingly, using data for the early 2000s Berger and Bristow (2009) evidence a negative correlation whereby countries which have a "better" competitiveness ranking also tended to have lower happiness scores.

${ }^{6}$ Total Factor Productivity (TFP) could also be used as a measure of competitiveness (McFetridge, 1995) but given the absence of reliable measures of TFP, i.e. the productivity of the capital and labour inputs combined, we have concentrated on labour productivity.

${ }^{7}$ GVA: Gross value added, which is very similar to the Gross Domestic Product (GDP) national accounts measure. GVA+ taxes on products - subsidies on production= GDP.

${ }^{8}$ Strictly, 144 countries plus Northern Ireland.

${ }^{9}$ Importantly, this is about Northern Ireland still doing badly but less so in a relative sense. Still lagging ranking behind many other advanced economies but to a lesser extent.

${ }^{10}$ That heterogeneity may be one reason why the WEF ranking has been found to be only weakly correlated with subsequent economic growth performance (Berger \& Bristow, 2009). ${ }^{11}$ Particularly, the Economic Advisory Group which advised the Minister for the Economy. ${ }^{12}$ The argument here is that it not only the net addition or growth to the stock of businesses, births minus deaths, which matters, but the absolute value of the birth and death rate. If the level of both business births and deaths is low that could be indicative of a lack of dynamism. 
${ }^{13}$ In the absence of any regional level data, Northern Ireland performance was proxied by that of the UK overall for ease of doing business, product market regulation, barriers to entrepreneurship and time taken to comply with tax payments.

${ }^{14}$ The Scorecard did include separate indicators relating to firm formation, churn in the stock of firms, FDI and venture capital.

${ }^{15}$ Does the fiscal transfer to support public spending from the UK government to Northern Ireland play a role? High life satisfaction could be partly a product of 'unearned consumption'. Northern Ireland's consumption was propped up by the transfer coming from those regions which have higher GVA per head, but a lower quality of life. Moreover, notwithstanding the assumption often made in welfare economics, individuals may not be the best judge of their well-being and in particular people in Northern Ireland may not be able to accurately judge what their quality of life actually is (Ha-Joon, 2013).

${ }^{16}$ There is a possible trade off between underpinning measurement of ranking and explaining the competitiveness performance. The particular circumstances which characterise Northern Ireland might imply a case for modifying the WEF questions but if that is done it may not be possible to integrate the Northern Ireland result into the WEF rankings. There may be scope for use of open questions to help explain competitiveness outcomes but this again would not help ranking.

${ }^{17}$ The Scorecard does include indicators relating to business environment but, in the absence of separate data for Northern Ireland, these were proxied by the UK average.

${ }^{18}$ See Byrne (2017).

${ }^{19}$ Byrne (2017) does spell out a rationale for the peer group with eight members although a case could be made for adding to that group. In Scotland a group of 12 comparators- advanced, small successful economies- has been used (The Sustainable Growth Commission, 2018).

${ }^{20}$ Admittedly, for action to happen this assumes government ministers are in place to take the necessary decisions. As of January 2019 Northern Ireland's devolved regional government was 
still non-operational (suspended in January 2017). The London government had yet to take back full responsibility in terms of direct rule. 